\title{
Towards an Ethical and Ecological Approach to Electricity Generation: A Comparative Analysis of Coal and Nuclear Power in the USA
}

\author{
Joseph R. Laracy ${ }^{1,2}$ (1) \\ ${ }^{1}$ Department of Systematic Theology, Seton Hall University, South Orange, NJ, USA \\ ${ }^{2}$ Department of Mathematics and Computer Science, Seton Hall University, South Orange, NJ, USA \\ Email: joseph.laracy@shu.edu
}

How to cite this paper: Laracy, J.R. (2020) Towards an Ethical and Ecological Approach to Electricity Generation: A Comparative Analysis of Coal and Nuclear Power in the USA. Open Journal of Ecology, 10, 370-379.

https://doi.org/10.4236/oje.2020.106023

Received: May 10, 2020

Accepted: June 9, 2020

Published: June 12, 2020

Copyright $\odot 2020$ by author(s) and Scientific Research Publishing Inc. This work is licensed under the Creative Commons Attribution-NonCommercial International License (CC BY-NC 4.0). http://creativecommons.org/licenses/by-nc/4.0/ (c) (i) (8) Open Access

\begin{abstract}
According to the US Energy Information Administration, about 4118 billion kilowatt-hours $(\mathrm{kWh})$ electricity was generated at large-scale generation facilities in 2019. About 63\% of this was from fossil fuels, e.g., coal, natural gas, petroleum, and other gases. Environmental exposure to particulates, sulfur dioxide, nitrogen oxides, mercury, arsenic, radioactive fly ash, and other pollutants are extremely detrimental to the human cardiovascular, respiratory, and nervous systems. Such exposure increases the risk of lung cancer, stroke, heart disease, chronic respiratory diseases, respiratory infections, and other illnesses. In light of the challenges associated with renewables providing large quantities of base load power, as well as other factors, the benefits offered by nuclear power should be reexamined by policy makers to move the country towards a more ecological and ethical method of electric power production. This paper offers a concise analysis of many of the salient issues, comparing electricity generation from coal plants and light water nuclear reactors.
\end{abstract}

\section{Keywords}

Nuclear Energy, Coal, Electric Power Generation, Ecology, Safety, Health

\section{Introduction}

Words such as "radiation," "nuclear," and "atomic" regrettably have a predominately negative connotation among the general public. The prevalent perception is that these words are synonymous with "cancer," "disease," and "death." Popular opinion rooted in these misconceptions has shown itself to be an impediment in the United States, as well as Europe, in the quest to develop a source of 
electric energy independent of fossil fuels with their accompanying negative health and environmental effects. Serious ethical discernment, supported by well-established principles of physics and engineering, must guide policy makers in strategic planning for the future of energy in the United States.

A correct understanding of radiation is an essential point of departure in such an endeavor. Most scientists and engineers are familiar with the two types of radiation: ionizing and non-ionizing. Ionizing radiation is sufficiently energetic to liberate an electron from an atom or molecule, and occurs in the form of $\alpha$ and $\beta$ particles, neutrons, fission fragments, heavy ions, high frequency UV light, $\mathrm{X}$-rays, and $\gamma$ rays. It is dangerous to living organisms because it can break chemical bonds and therefore damage DNA, leading to mutations. In higher doses it causes radiation burns and death. However, ionizing radiation is harnessed for health purposes as well, such as medical imaging and cancer treatment. Non-ionizing radiation is often not harmful to living tissues as low frequency electromagnetic (EM) radiation such as radio frequency (RF), microwave, infrared (IR), and visible light usually cannot damage human tissue. The upper frequencies of non-ionizing radiation (much of the spectrum of UV light), which lies between visible light and X-rays on the EM spectrum, are however sufficiently energetic to cause sunburn and skin cancer, similar to ionizing radiation.

It is important to educate the public about the "ordinariness" of radiation exposure for life on Earth. Half of the radiation to which Americans are exposed originates from natural sources. Thirty-seven percent arises from radioactive gases such as radon (a radioactive element whose most stable isotope is ${ }^{222} \mathrm{Rn}$ and occurs as a natural decay product of uranium) and thoron (a particular radioactive isotope of radon, ${ }^{220} \mathrm{Rn}$, that is a natural decay product of the most stable thorium isotope, ${ }^{232} \mathrm{Th}$ ). Five percent derives from outer space (e.g., cosmic rays), another five percent from inside the earth (e.g., ${ }^{238} \mathrm{U}$ in rocks), and three percent from soil (e.g., ${ }^{40} \mathrm{~K}$ ). The other half of the radiation to which Americans are exposed derives from man-made sources: $36 \%$ from medical procedures (e.g., CT Scan), $12 \%$ from nuclear medicine (e.g., SPECT), and $2 \%$ from consumer products (e.g., smoke detectors). Only $0.1 \%$ of radiation exposure is a result of industrial processes [1].

\section{Ecological Question}

In the discernment about the future of power generation, the fundamental question that must be asked is: What is the most ethical way to produce electric power in the United States that respects the environment and human health? In answering the question, policy makers should always be seeking the common good, i.e., "the sum total of social conditions which allow people, either as groups or as individuals, to reach their fulfillment more fully and more easily" [2].

An appropriate starting point is to consider the current state of electric power production. In 2019, the United States generated about 4118 billion kilo- 
watt-hours $(\mathrm{kWh})$ of electricity. Fission reactors produced $19.7 \%$ of the power while about $63 \%$ of the electricity generated was from fossil fuel $(23.5 \%$ coal, $38.4 \%$ natural gas, $0.5 \%$ petroleum, and $0.3 \%$ other gases). Renewables accounted for the other $17.5 \%$. Within this category, only $1.8 \%$ was captured from solar panels, while $6.6 \%$ came from hydropower and $7.3 \%$ from wind [3].

An important distinction must be made between what are referred to as "base load" and "peaker" plants. Base load power generation must generate sufficient electricity to cover the minimum consumer demand. It relies on reactor technologies that are efficient but not highly adjustable to varying demand scenarios. Fission and coal plants are the classic base load sources. Peaker plants on the other hand are generally not as efficient and cannot satisfy the base load demands filled by nuclear and coal reactors. However, they can be turned on and off with relative ease to stay ahead of peak demand, e.g., on a hot sunny day when all air-conditioners are running on maximum. It is one thing to activate a petroleum combustion plant and quite another to bring a fission reactor online. As a result, national electric systems rely on a combination of base and peaker plants.

For the purposes of this paper, the two primary base power options will be analyzed: nuclear and coal. Following the important safety framework developed by Haddad and Dones, at the time staff members in the IAEA Division of Nuclear Safety, four primary risks categories must be considered:

- Immediate Occupational Risks,

- Delayed Occupational Risks,

- Immediate Public Risks, and

- Delayed Public Risks [4].

The focus of the analysis is on health and environmental effects from these two approaches. The risks of "severe" accidents will also be considered.

\section{Principles of Light Water Reactors and Coal Power Plants}

There are two types of light water reactors (LWRs) in the USA: 64 pressurized water reactors (PWRs) and 32 boiling water reactors (BWRs) for a total of 96 LWRs [5]. LWRs are called "light" because they utilize normal water as opposed to heavy water (deuterium oxide) for cooling and neutron moderation. The fuel is uranium; over $99 \%$ of naturally occurring uranium is ${ }^{238} \mathrm{U}$. However, in order to produce a self-sustaining process, a "critical" chain reaction is necessary. Therefore, uranium ore $\left(\mathrm{U}_{3} \mathrm{O}_{8}\right)$ is processed and enriched to a level where $~ 3 \%$ is ${ }^{235} \mathrm{U}$. Unlike ${ }^{238} \mathrm{U}$, ${ }^{235} \mathrm{U}$ is fissile, i.e., a neutron of any energy level (released in the fission reaction) is capable of causing another nucleus to fission. The enrichment process produces uranium hexafluoride $\left(\mathrm{UF}_{6}\right)$ which is then converted to uranium dioxide $\left(\mathrm{UO}_{2}\right)$ powder. The powder is transformed into pellets that are inserted into alloy tubes, commonly referred to as fuel rods [6].

In a PWR, the primary coolant is injected under pressure into the reactor where the thermal energy from the fission reaction heats it. The water is then pumped to a steam generator in which thermal energy is transferred to the sec- 
ondary loop. This secondary system spins a turbine which converts the thermal energy to mechanical energy. Lastly, a generator converts the mechanical energy into electric energy. In a variety of ways, PWRs offer a number of safety advantages compared to BWRs. Firstly, PWRs tend to be more stable because they will usually produce less power as temperature increases. Additionally, by separating the coolant system into a primary and secondary, the water in the secondary does not become radioactive. Finally, PWRs are passively safe. In the event that external power is lost (e.g., from an earthquake), the control rods which are held in position by electromagnets fall by the force of gravity and SCRAM the reactor [7].

On the other hand, a BWR (not surprisingly) boils water within the reactor and therefore creates steam in the reactor core which is transported directly to a turbine system. While the reactor vessel is subject to significantly less pressure compared to a PWR and it operates at lower core temperatures, fuel rods are inserted by a hydraulic system from beneath the reactor. With the loss of external power, it is more likely for the reactor to go super-critical. The Fukushima Daiichi Nuclear Power Plant in Japan that suffered meltdowns in 2011 utilized BWRs [8].

Coal is the most abundant fossil fuel on Earth and is found in large quantities throughout the United States. The high-level design of a coal-based electric power plant is quite simple. Coal is oxidized in a large furnace and the heat from this exothermic reaction is used to boil water. The steam produced by the furnace is routed to spin a turbine that converts the thermal energy to mechanical energy. Finally, a generator converts the mechanical energy into electric energy. The water is cooled and then recycled, often through the use of a nearby body of water.

\section{Analysis}

Despite the overall simplicity of the coal cycle, the significant analysis by Haddad and Dones at the International Atomic Energy Agency (IAEA) Division of Nuclear Safety found in a comparative study of electric power generation systems, that the immediate occupational risk for coal plants is $8-10$ times higher than for LWRs. The immediate occupational risks associated with coal are of the same order of magnitude as those of renewable systems but noticeably higher than those for natural gas and oil. Uranium and coal mining are the primary sources of delayed occupational risk. However, on the basis of a normalized unit of electricity generated, underground coal mining was found to be more dangerous [9].

Immediate public risks are largely a result of transportation accidents. Therefore, the method of transport and the distances involved affects the likelihood of an accident. Because of the very large quantities of fuel necessary for a coal plant, the coal cycle was found to have the highest immediate public risk. For the very same reason, the immediate public risk for LWRs is 10 - 100 lower than all other electric generation options. Delayed public risks are more difficult to quantify; 
therefore, greater uncertainty remains in the results of the IAEA analysis. However, a general trend that was discovered was that the delayed public risk for coal and petroleum plants was at least 10 times greater than for natural gas and nuclear systems [10].

One of the sources of delayed public risks is the emission and production of residuals. It is important not only to consider $\mathrm{CO}_{2}$, but also $\mathrm{NO}_{\mathrm{x}}, \mathrm{SO}_{\mathrm{x}}$, land use, solid waste, and particulates released into the air. Aggregating emissions into categories, one notices that the total airborne emissions (measured in mass per unit energy) are very close for all the fossil fuel options: natural gas, coal, and petroleum. However, coal produced the most particulates and consumed the most land among the three. Petroleum released the most $\mathrm{NO}_{\mathrm{x}}$, while natural gas produced the greatest quantity of $\mathrm{SO}_{\mathrm{x}}$. In comparison with nuclear power, the coal cycle released significantly more particulates, produced more solid waste, ejected more $\mathrm{NO}_{\mathrm{x}}, \mathrm{SO}_{\mathrm{x}}$, and $\mathrm{CO}_{2}$, as well as consumed more land [11].

Among particulates released in power production, a particularly serious health concern associated with coal plants is the production of fly ash. Fly ash is a byproduct from coal production that includes uranium, thorium, potassium, and their decay product-radium [12]. While these elements are only found in trace amounts in coal ore, the combustion process concentrates them by a factor of 10. According to research done at Oak Ridge National Laboratory (ORNL), fly ash disperses 100 times more radiation than an LWR producing the same amount of energy. In 1978, J.P. McBride of ORNL conducted a study in Tennessee and Alabama to find out the amount of radiation absorbed in the bones of those living near coal plants. Some of these subjects had received up to 18 millirems. In contrast, for those living outside the two nuclear sites, effective doses of 3 - 6 millirems was found over the same period. McBride also discovered that those who ate food grown predominately in the local area near the power plants received 50 - 200 times the radiation doses if they lived near a coal plant rather than a nuclear one. In addition, coal plants release acid rain producing $\mathrm{NO}_{\mathrm{x}}$ and $\mathrm{SO}_{\mathrm{x}}$, as well as smog forming $\mathrm{N}_{2} \mathrm{O}$ which $\mathrm{McBride}$ and his fellow researchers convincingly argue is a greater health risk than radiation [13].

A special type of delayed public risk emerges as a result of the nuclear fuel cycle. Spent nuclear fuel (SNF) is composed of highly radioactive uranium, plutonium, as well as other fission products. Therefore, after it has been removed from the reactor, it is typically stored in spent fuel "ponds" for at least a year in order to facilitate the cooling of the materials and shield from radioactivity. At some nuclear power sites, SNF remains for decades. SNF may be moved to a reprocessing facility where, through chemical decomposition, particular isotopes are extracted. For example, reprocessed uranium $\left(99 \%{ }^{238} \mathrm{U}\right)$ can be used to create new fuel for an LWR. Noble metals (e.g., platinum) can be extracted for industrial purposes as well as beneficial radionuclides for medical applications. Weapons grade plutonium is also found in SNF and therefore a proliferation risk emerges if the materials are not properly safe-guarded [14].

With or without reprocessing, SNF requires long term storage. The United 
States had been working for decades, spending more than $\$ 15$ billion, to provide a secure facility in the deep geological formation of Yucca Mountain. This nuclear waste repository would have successfully shielded human populations as well as protected the environment for thousands of years. In 2002, the US Congress and President George W. Bush approved the site and the Department of Energy filed a license application with the NRC [15]. Unfortunately, President Barack H. Obama, fulfilling a 2008 campaign promise, cancelled the project by withdrawing federal funding in 2011 (under strong objections from the NRC) [16]. As a result, most nuclear power plants in the USA have resorted to the storage of waste on-site in steel and concrete casks.

A special class of immediate public risk must also be considered: the risk of "severe accidents," i.e., significant off-site risk to people, property, and the environment. Somewhat surprisingly, as a result of their extensive research, Haddad and Dones point out that "on the basis of a normalized per unit of electricity produced, it appears that the hydroelectric option has caused more immediate fatalities from severe incidents than any other energy source" [17]. Many Americans are surprised to learn that since commercial nuclear power first emerged in 1958, there has not been a single death attributed to a severe accident.

The most severe incident occurred at the Three Mile Island Nuclear Generating Station in 1979. In that accident, a design-error allowed a pilot-operated relief valve (PORV) in the primary system to remain open when the control panel indicated that it was closed. The control panel indicated the state of the solenoid that controlled the coolant valve, not the actual position of the valve. As a result, nuclear reactor coolant was discharged and a partial melt-down occurred in one of the two reactors [18].

Although this was the worst nuclear accident in the history of commercial nuclear power in the United States, the small amounts of radioactive gases and radioactive iodine released were quite insignificant. According to the American Nuclear Society,

The average radiation dose to people living within ten miles of the plant was eight millirems, and no more than 100 millirems to any single individual. Eight millirems is about equal to a chest X-ray, and 100 millirems is about a third of the average background level of radiation received by US residents in a year [19].

There are zero cases of cancer credibly attributed to the Three Mile Island accident.

The severe accident record associated with the coal cycle is not as clean. In coal mining disasters, suffocation, gas poisoning, roof collapse, and gas explosions have claimed many lives. According to research done in 2006 by Katherine Torres, an expert in environmental, health, and safety management, the USA averages around thirty mining deaths each year [20]. Data from the Mine Safety and Health Administration (MSHA) and Bureau of Labor Statistics (BLS) indicates that "U.S. coal mining fatal injuries decreased 67 percent from 1990 to 
2005, while the total injury rate in coal mining from 1990 to 2004 experienced a 51 percent decrease" [21]. Although exact figures are not known, the total death count in the United States from coal mining disasters may have exceeded 100,000 in the twentieth century [22].

Finally, after considering the risks to human health and the environment, it is appropriate to briefly consider the economics of electric power generation systems. It can be difficult to compare nuclear plants with coal plants because their cost structure varies significantly. For example, there are very high capital costs for nuclear power compared to coal. However, one finds significantly lower fuel costs even when the cost of uranium processing and enrichment as well as fuel element fabrication and disposal are included. An analysis done by the US Nuclear Energy Institute (NEI), a nuclear industry trade association, shows "that for a coal-fired plant $78 \%$ of the cost is the fuel, for a gas-fired plant the figure is $89 \%$, and for nuclear the uranium is about $14 \%$, or double that to include all front end costs" [23]. This of course makes fossil fuel plants very sensitive to fluctuating prices.

In 2012, the NEI conducted a study, comparing the costs of electricity with nuclear generation at $2.40 \AA / \mathrm{kWh}$, coal at $3.27 \mathrm{\varsigma} / \mathrm{kWh}$, gas at $3.40 \mathrm{\phi} / \mathrm{kWh}$, and petroleum at $22.48 \mathrm{\$} / \mathrm{kWh}$ [24]. It must be noted that the NEI study only includes fuel, operation, and maintenance costs. It excludes capital costs because these vary significantly depending on plant age, particular utility companies, and individual states. The US EIA conducts studies every year on the levelized cost of energy/electricity (LCOE), a measure of the average net present cost of electricity generation for a generating plant over its lifetime. LCOE gives the average revenue per unit of electricity produced that would be required to recover the costs of building and operating a plant during its presumed life cycle. This is based on the cost of capital, fuel, operations, maintenance, financing, as well as the utilization rate. The latest data is shown below in Table 1 , sorted from highest to lowest simple average LCOE for the US by 2025 (as of 2020) in \$/MWh [25].

Table 1. Projected LCOE in the U.S. by 2025 (as of 2020) \$/MWh (Source: US EIA).

\begin{tabular}{ccccc}
\hline Plant Type & Min & Simple Average & $\begin{array}{c}\text { Capacity } \\
\text { Weighted Average }\end{array}$ & Max \\
\hline Wind, offshore & 102.68 & 122.25 & 115.04 & 155.55 \\
Biomass & 86.19 & 94.83 & $\mathrm{NB}$ & 139.96 \\
Advanced Nuclear & 71.9 & 81.65 & $\mathrm{NB}$ & 92.04 \\
Ultra-supercritical coal & 65.1 & 76.44 & $\mathrm{NB}$ & 91.27 \\
Combustion Turbine & 58.48 & 66.62 & 68.71 & 81.37 \\
Hydroelectric & 35.37 & 52.79 & 39.54 & 63.24 \\
Wind, onshore & 28.72 & 39.95 & 34.1 & 62.72 \\
Combined cycle & 33.35 & 38.07 & 36.61 & 45.31 \\
Geothermal & 35.13 & 37.47 & 37.47 & 39.6 \\
Solar photovoltaic (PV) & 29.75 & 35.74 & 32.8 & 48.09 \\
\hline
\end{tabular}




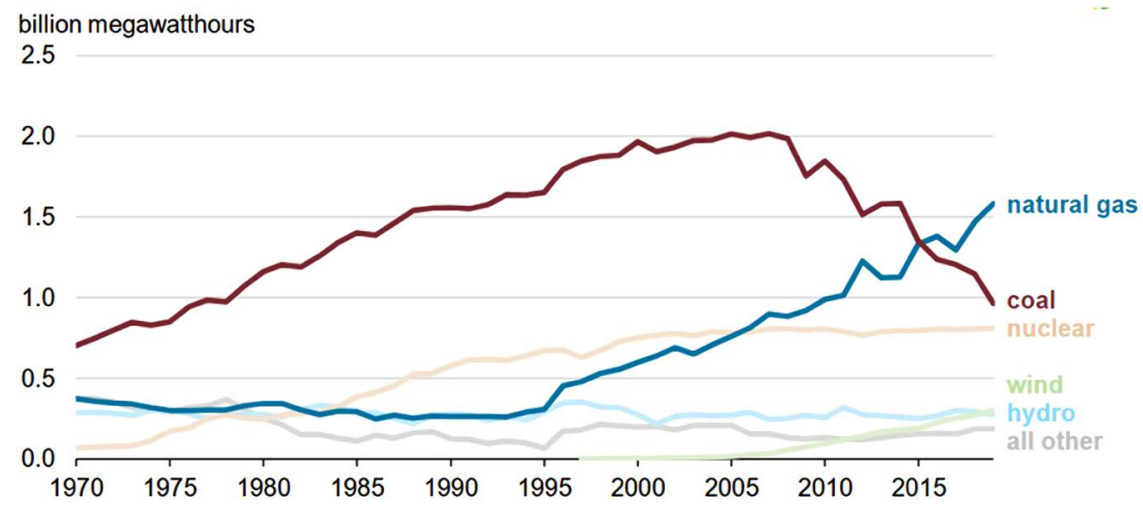

Figure 1. US annual electricity generation by energy source (1970-2019) (Source: US EIA).

Interestingly, the output from coal-fired plants dropped to 966,000 GWh in 2019, the lowest level since 1976 [26]. See Figure 1.

\section{Conclusion}

Considering immediate occupational risks, delayed occupational risks, immediate public risks, delayed public risks, as well as the risk of severe accidents and cost, the case to move away from coal-based sources of electric power to nuclear is compelling. The greatest difficulties encountered thus far in the United States have been political. The fear of ordinary citizens, and their elected officials, has been an impediment to both the construction of new LWRs as well as permanent SNL disposal facilities. Science education about the true risks for humans and the environment arising from the continued use of fossil fuels to generate electricity should be a persuasive motive for change.

\section{Acknowledgements}

The author is grateful for the comments from the reviewers.

\section{Conflicts of Interest}

The author declares no conflicts of interest regarding the publication of this paper.

\section{References}

[1] US Nuclear Regulatory Commission (accessed 1 May 2020) Sources of Radiation. http://www.nrc.gov/about-nrc/radiation/around-us/sources.html

[2] Second Vatican Council (1965) Gaudium et Spes, $26 \$ 1$.

[3] US Energy Information Administration (accessed 1 May 2020) What Is U.S. Electricity Generation by Energy Source? http://www.eia.gov/tools/faqs/faq.cfm?id=427\&t=3

[4] Haddad, S. and Dones, R. (1991) Comparative Health and Environmental Risks for Various Energy Sources. IAEA Bulletin, 3, 14-19.

[5] US Nuclear Regulatory Commission (accessed 1 May 2020) Operating Nuclear 
Power Reactors (by Location or Name). http://www.nrc.gov/info-finder/reactor/

[6] Murray, R.L. and Holbert, K.E. (2020) Nuclear Energy. An Introduction to the Concepts, Systems, and Applications of Nuclear Processes. 8th Edition, Butterworth-Heinemann, Oxford, UK.

[7] Glasstone, S. and Sesonske, A. (1994) Nuclear Reactor Engineering: Reactor Systems Engineering. Springer, New York.

[8] Ishikawa, M. (2015) A Study of the Fukushima Daiichi Nuclear Accident Process: What Caused the Core Melt and Hydrogen Explosion? Springer, New York.

[9] Haddad and Dones (1991) Comparative Health and Environmental Risks for Various Energy Sources. 15.

[10] Ibid.

[11] Ibid., 17.

[12] US Environmental Protection Agency (accessed 15 April 2020) TENORM: Coal Combustion Residuals. https://www.epa.gov/radiation/tenorm-coal-combustion-residuals

[13] Hvistendahl, M. (13 December 2007) Coal Ash Is More Radioactive than Nuclear Waste. Scientific American.

http://www.scientificamerican.com/article.cfm?id=coal-ash-is-more-radioactive-tha n-nuclear-waste

[14] Murray, R.L. and Holbert, K.E. (2020) Nuclear Energy. An Introduction to the Concepts, Systems, and Applications of Nuclear Processes. 8th Edition, Butterworth-Heinemann, Oxford, UK, Ch. 22.

[15] World Nuclear News (6 August 2008) Yucca Mountain Cost Estimate Rises to \$96 Billion.

http://www.world-nuclear-news.org/WR-Yucca_Mountain_cost_estimate_rises_to_ 96_billion_dollars-0608085.html

[16] The Department of Defense and Full-Year Continuing Appropriations Act, Passed on 14 April 2011.

[17] Haddad and Dones (1991) Comparative Health and Environmental Risks for Various Energy Sources. 17.

[18] US Nuclear Regulatory Commission (accessed 30 December 2019) Backgrounder on the Three Mile Island Accident.

http://www.nrc.gov/reading-rm/doc-collections/fact-sheets/3mile-isle.html

[19] American Nuclear Society (accessed 2 January 2020) What Happened and What Didn't in the TMI-2 Accident.

http://www.ans.org/pi/resources/sptopics/tmi/whathappened.php

[20] Torres, K. (12 March 2006) Breathing Easy: Respiratory Protection in Coal Mines. http://ehstoday.com/ppe/respirators/ehs_imp_38114

[21] Ibid.

[22] Hickham, H. (7 April 2010) Former Miner Explains Culture of Mining. Michel Martin (National Public Radio), ed., Transcript.

http://www.npr.org/templates/story/story.php?storyId=125676950

[23] US Nuclear Energy Institute report cited in Zohuri, B. and McDaniel, P. (2015) Thermodynamics in Nuclear Power Plant Systems. Springer, New York, 564. World Nuclear Association, “The Economics of Nuclear Power". http://www.world-nuclear.org/info/Economic-Aspects/Economics-of-Nuclear-Pow $\underline{\text { er/ }}$ 
[24] Nuclear Energy Institute (2018) “U.S. Electricity Production Costs" cited in American Nuclear Society Center for Nuclear Science and Technology Information, "Nuclear Energy". http://nuclearconnect.org/know-nuclear/applications/energy

[25] US Energy Information Administration (February 2020) Levelized Cost and Levelized Avoided Cost of New Generation Resources in the Annual Energy Outlook 2020. https://www.eia.gov/outlooks/aeo/pdf/electricity_generation.pdf

[26] US Energy Information Association (May 12, 2020) U.S. Coal-Fired Electricity Generation in 2019 Falls to 42-Year Low.

https://www.eia.gov/todayinenergy/detail.php?id=43675 